\title{
PERBANDINGAN KARAKTERISTIK MANAJEMEN RISIKO KONSTRUKSI PADA KONTRAKTOR BUMN DAN SWASTA
}

\author{
Roi Milyardi \\ Dosen, Program Studi Teknik Sipil, Fakultas Teknik, Universitas Kristen Maranatha \\ Email: roi.milyardi@maranatha.edu
}

\begin{abstract}
ABSTRAK
Adanya peningkatan volume pekerjaan konstruksi terkait program pemerintah Indonesia dalam pembangunan infrastruktur, membuat sektor konstruksi mengalami pertumbuhan yang cukup besar dibanding sektor ekonomi lainnya, dimana entitas yang mendominasi adalah kontraktor BUMN dan kontraktor swasta. Perbedaan utama kontraktor BUMN dan swasta tersebut adalah aspek finansial. Dalam usaha pendanaan investor, langkah IPO (Initial Public Offering) dan strategi perusahaan, terutama manajemen risiko menjadi hal penting untuk meyakinkan investor untuk berinvestasi pada perusahaan masing-masing. Oleh karena itu, pada penelitian ini bertujuan membahas perbandingan karateristik identifikasi risiko dan respon risiko dalam manajemen risiko perusahaan pada kontraktor BUMN dan kontraktor swasta yang memiliki manfaat pada pengambilan keputusan investor sektor konstruksi. Analisis dilakukan dengan analisis perbandingan kualitatif sederhana manajemen risiko pada studi kasus 4 kontraktor BUMN dan 4 kontraktor swasta yang telah melakukan IPO. Hasil analisis menyimpulkan bahwa pada identifikasi risiko, kontraktor BUMN memiliki top risk secara umum pada risiko-risiko di tingkat perusahaan pada hirarki proses konstruksi, sementara pada kontraktor swasta secara umum berfokus pada risiko-risiko di tingkat proyek pada hirarki proses konstruksi. Perbedaan signifikan yang ditemukan adalah pada perencanaan respons terhadap risiko persaingan usaha, dimana kontraktor BUMN berfokus pada tingkat perusahaan dan memanfaatkan hubungan entitas dengan pemerintah, sementara kontraktor swasta berfokus pada tingkat meningkatkan kuantitas dan kualita proyek yang dikerjakan.
\end{abstract}

Kata Kunci: manajemen risiko, kontraktor, BUMN, perusahaan swasta

\begin{abstract}
An increase in the volume of construction work related to the Indonesian government's program in infrastructure development, has made the construction sector experience a sizeable growth compared to other economic sectors, where the dominant entities are state-enterprise and private contractors. The main difference between the state-enterprise and private contractors is the financial aspect. In the business of investor funding, IPO (Initial Public Offering) and corporate strategy, especially risk management, are important to convince investors to invest in their respective companies. Therefore, this study aims to discuss the comparison of the characteristics of risk identification and risk response in the company's risk management of state-owned and private contractors who have benefits in the construction sector investor decision making. The analysis was carried out with a simple qualitative comparison of risk management in a case study of 4 state-enterprise contractors and 4 private contractors who had conducted an IPO. The results of the analysis conclude that in the identification of risks, state-enterprise contractors have a general top risk on risks at the company level in the construction process hierarchy, while private contractors generally focus on project-level risks in the construction process hierarchy. A significant difference found was in the planning of responses to business competition risks, where state-enterprise contractors focused on the company level and utilized the entity's relationship with the government, while private contractors focused on increasing the quantity and quality of projects undertaken.
\end{abstract}

Keywords: Risk Management, contractor, state enterprise, private enterprise 


\section{Pendahuluan}

Dalam rentang waktu 2015 hingga diproyeksikan 2025, Pemerintahan Indonesia memfokuskan melakukan percepatan pembangunan di bidang infrastruktur (Kantor Staf Presiden Republik Indonesia, 2016). Dengan adanya penambahan volume pembangunan infrastruktur yang menjadi fokus pemerintah, secara langsung akan berdampak terhadap PDB (Pendapatan Domestik Bruto) untuk sektor konstruksi. Dari data yang ada, selama kurun waktu 2014-2018, sektor konstruksi secara konstan memiliki distribusi PDB sebesar $10.21 \%$ ditunjukkan pada Tabel 1 dan Gambar 1. Meskipun memiliki distribusi yang konstan, sektor konstruksi memiliki pertumbuhan paling besar dan konstan distribusi PDB dibanding sektor lainnya, yaitu pada kisaran 5.22\%-6.97\% ditunjukkan pada Tabel 2.

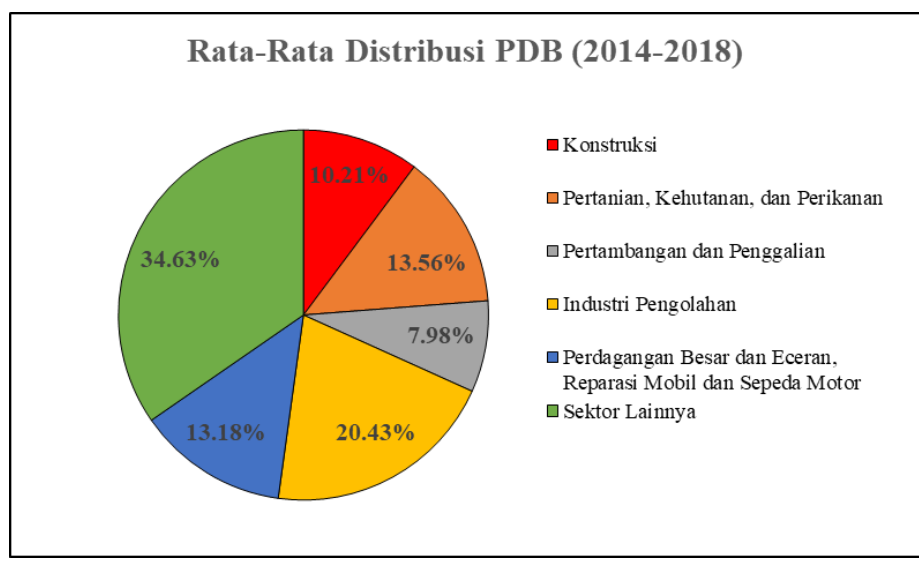

Gambar 1. Distribusi PDB Rata-Rata 2014-2018

Sumber: Badan Pusat Statistik, 2014, 2015, 2016, 2017, 2018, 2019, 2020

Tabel 1. Distribusi PDB 2014-2018

\begin{tabular}{ccccccc}
\hline Sektor Ekonomi & $\mathbf{2 0 1 4}$ & $\mathbf{2 0 1 5}$ & $\begin{array}{r}\text { Tahun } \\
\mathbf{2 0 1 6}\end{array}$ & $\mathbf{2 0 1 7}$ & $\mathbf{2 0 1 8}$ & $\begin{array}{c}\text { Rata- } \\
\text { Rata }\end{array}$ \\
\hline $\begin{array}{c}\text { Konstruksi } \\
\text { Pertanian, Kehutanan, } \\
\text { dan Perikanan }\end{array}$ & $9.86 \%$ & $10.21 \%$ & $10.38 \%$ & $10.26 \%$ & $10.36 \%$ & $10.21 \%$ \\
$\begin{array}{c}\text { Pertambangan dan } \\
\text { Penggalian }\end{array}$ & $9.83 \%$ & $7.65 \%$ & $7.18 \%$ & $7.15 \%$ & $8.11 \%$ & $7.98 \%$ \\
$\begin{array}{c}\text { Industri Pengolahan } \\
\text { Perdagangan Besar }\end{array}$ & $21.08 \%$ & $20.99 \%$ & $20.51 \%$ & $19.93 \%$ & $19.66 \%$ & $20.43 \%$ \\
$\begin{array}{c}\text { dan Eceran, Reparasi } \\
\text { Mobil dan Sepeda } \\
\text { Motor }\end{array}$ & $13.43 \%$ & $13.30 \%$ & $13.18 \%$ & $12.98 \%$ & $13.01 \%$ & $13.18 \%$ \\
$\quad$ Sektor Lainnya & $32.47 \%$ & $34.36 \%$ & $35.27 \%$ & $35.72 \%$ & $35.33 \%$ & $34.63 \%$ \\
\hline$\quad$ Sumber Ban
\end{tabular}

Sumber: Badan Pusat Statistik, 2014, 2015, 2016, 2017, 2018, 2019, 2020 
Berdasarkan keterangan Kementetian Keuangan Republik Indonesia, sumber pendanaan untuk pembangunan infrastruktur terdapat 3 sumber, yaitu APBN, penugasan Proyek kepada BUMN, dan kerja sama dengan pihak swasta (Pratama, 2017).

Tabel 2. Pertumbuhan Distribusi PDB 2014-2018

\begin{tabular}{ccccc}
\hline \multirow{2}{*}{ Sektor Ekonomi } & \multicolumn{4}{c}{ \% Pertumbuhan PDB } \\
\cline { 2 - 5 } & $\mathbf{2 0 1 4}$ & $\mathbf{2 0 1 5}$ & $\mathbf{2 0 1 6}$ & $\mathbf{2 0 1 7}$ \\
\hline Konstruksi & $6.97 \%$ & $6.36 \%$ & $5.22 \%$ & $6.79 \%$ \\
\hline $\begin{array}{c}\text { Pertanian, Kehutanan, dan } \\
\text { Perikanan }\end{array}$ & $4.24 \%$ & $3.75 \%$ & $3.36 \%$ & $3.81 \%$ \\
\hline Pertambangan dan Penggalian & $0.43 \%$ & $3.42 \%$ & $0.95 \%$ & $0.69 \%$ \\
\hline Industri Pengolahan & $4.64 \%$ & $4.33 \%$ & $4.26 \%$ & $4.27 \%$ \\
\hline $\begin{array}{c}\text { Perdagangan Besar dan Eceran, } \\
\text { Reparasi Mobil dan Sepeda } \\
\text { Motor }\end{array}$ & $5.18 \%$ & $2.54 \%$ & $4.03 \%$ & $4.44 \%$ \\
\hline \begin{tabular}{c} 
Por \\
\hline
\end{tabular} & & & \\
\hline
\end{tabular}

Sumber: Badan Pusat Statistik, 2020

Skema pembiayaan infrastruktur dengan melibatkan badan usaha (BUMN maupun badan usaha swasta) diatur melalui PerPres No.38 Tahun 2015 tentang kerjasama pemerintah dengan badan usaha dalam penyediaan infrastruktur. Dalam pemenuhan infrastruktur, tentunya sektor konstruksi yang didominasi kontraktor konstruksi berperan besar dalam kegiatan pembangunan infrastruktur tersebut. Skema KPBU yang dipilih oleh pemerintah melibatkan BUMN dan badan usaha, tentunya melibatkan kontraktor. Namun dalam pemenuhan kebutuhan finansial proyek yang ditangani, kontraktor BUMN memiliki alternatif yang lebih dibanding kontraktor swasta, yaitu adanya fasilitas penyertaan modal negara yang diatur melalu PP No.72 Tahun 2016, dimana prinsip penyertaan modal negara tersebut dimaksudkan untuk memperbaiki struktur permodalan BUMN dan meningkatkan kapasitas usaha BUMN. Kontraktor BUMN sebagai, state enterprise pemerintah dalam bidang infrastruktur akan terlibat langsung dalam pembangunan infrastruktur. Sementara kontraktor swasta memiliki peluang untuk berpartisipasi langsung membangun infrastruktur maupun terlibat dalam membangunan fasilitas pembangunan ekonomi yang didukung infrastruktur yang telah dibangun.

Alternatif lain dalam pemenuhan finasial kontraktor yang umum dipakai adalah pilihan Go-Public / Initial Public Offering (IPO). Alternatif IPO memberikan kesempatan bagi investor secara umum / publik membantu pendanaan modal perusahaan kontraktor. Pada bursa saham Bursa Efek Indonesia (BEI) tercatat 17 perusahaan kontraktor bidang konstruksi, yang terdiri 13 kontraktor swasta dan 4 kontraktor BUMN. 
Tabel 3. Daftar Perusahaan Kontraktor IPO

\begin{tabular}{cc}
\hline Kode Saham & Perusahaan \\
\hline ACST & PT Acset Indonusa Tbk. \\
\hline ADHI & PT Adhi Karya (Persero) Tbk. \\
\hline CSIS & PT Cahayasakti Investindo Sukses Tbk. \\
\hline DGIK & PT Nusa Konstruksi Enjiniring Tbk. \\
\hline IDPR & PT Indonesia Pondasi Raya Tbk. \\
\hline JKON & PT Jaya Konstruksi Manggala Pratama Tbk. \\
\hline MTRA & PT Mitra Pemuda Tbk. \\
\hline NRCA & PT Nusa Raya Cipta Tbk. \\
\hline PBSA & PT Paramita Bangun Sarana Tbk. \\
\hline PTPP & PT PP (Persero) Tbk. \\
\hline SKRN & PT Superkrane Mitra Utama Tbk. \\
\hline SSIA & PT Surya Semesta Internusa Tbk. \\
\hline TOPS & PT Totalindo Eka Persada Tbk. \\
\hline TOTL & PT Total Bangun Persada Tbk. \\
\hline WEGE & PT Wijaya Karya Bangunan Gedung Tbk. \\
\hline WIKA & PT Wijaya Karya (Persero) Tbk. \\
\hline WSKT & PT Waskita Karya (Persero) Tbk. \\
\hline
\end{tabular}

Sumber: PT. Bursa Efek Indonesia, 2020

Sebagai langkah strategi perusahaan menarik investor dan bentuk pertanggungjawaban kepada investor, setiap perusahaan yang telah melakukan Initial Public Offering (IPO) memiliki laporan tahunan/annual report. Dalam laporan tahunan dijabarkan berbagai aspek kinerja perusahaan, mulai dari keuangan hingga manajemen risiko. Manajemen risiko perusahaan menjadi salah satu hal yang penting diketahui oleh para investor, selain parameter investasi lainnya, untuk mengetahui bagaimana perusahaan mengidentifikasi risiko dan menentukan respon terhadap risiko sesuai dengan risk appetite perusahaan melalui berbagai standar sistem manajemen risiko perusahaan masing-masing.

Dengan adanya perbedaan fasiltias pendanaan, serta pentingnya manajemen risiko pada perusahaan kontraktor pada tingkat perusahaan dan proyek, melalui penelitian ini akan dibahas perbandingan karateristik identifikasi risiko dan respon risiko dalam manajemen risiko perusahaan pada kontraktor BUMN dan kontraktor swasta. Studi kasus pada penelitian ini dilakukan pada 8 kontraktor yang telah melakukan IPO, terdiri dari 4 kontraktor BUMN dan 4 kontraktor swasta dengan analisis perbandingan kualitatif sederhana, dimana data analsis manajemen risiko didapatkan melalui data sekunder 
annual report dan ringkasan kinerja saham perusahaan dalam rentang waktu 2014-2018 yang dipublikasi oleh Bursa Efek Indonesia.

\section{Tinjauan Pustaka}

\subsection{Manajemen Risiko Konstruksi}

Risiko adalah variasi dalam hal-hal yang mungkin yang terjadi secara alami atau kemungkinan terjadinya peristiwa di luar yang diharapkan, yang merupakan ancaman terhadap properti dan keuntungan finansial akibat bahaya yang terjadi (Labombang, 2011). Sektor konstruksi yang memiliki basis bisnis berupa proyek konstruksi, dimana setiap proyek konstruksi memiliki karakteristik unik dengan berbagai kompleksitasnya, sangat berkaitan erat dengan risiko. Manajemen risiko pada sektor konstruksi dibutuhkan untuk mengidentifikasi dan mengelola risiko yang ada pada proses konstruksi. Tanpa adanya manajemen risiko pada proyek kosntruksi, risiko berpotensi menyebabkan proyek konstruksi, yang menjadi bisnis inti sektor konstruksi, berjalan tidak sesuai rencana yang menimbulkan berbagai kerugian. Project Management Institute (2017) meendefinisikan proses manajemen risiko pada proyek, yang secara umum telah diadopsi pada proyek konstruksi yang ditunjukkan pada Gambar 2.

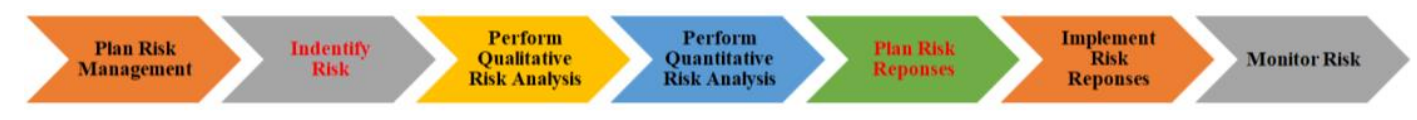

Gambar 2. Tahapan Proses Manajemen Risiko Proyek (Project Management Institute, 2017)

Manajemen risiko proyek terdiri dari beberapa tahapan berikut (Project Management Institute, 2017):

a. Perencanaan manajemen risiko, proses mendefinisikan bagaimana menerapkan aktivitas manajemen risiko pada proyek;

b. Identifikasi risiko, proses mengidentifikasi risiko proyek individu yang merupakan sumber risiko proyek secara keseluruhan serta mendokumentasikan karakteristik risiko yang ada;

c. Analisis risiko kualitatif, proese memprioritaskan risiko proyek individu untuk analisis lebih lanjut dengan menilai kemungkinan kejadian dan dampak dari risiko; 
d. Analisis risiko kuantitatif, proses analisis numerik yang mengkombinasikan efek dari identifikasi risiko pada tahap sebelumnya terhadap tujuan proyek secara keseluruhan;

e. Perencanaan respon risiko, proses mengembangkan alternatif ataupun strategi untuk menghadapi seluruh risiko yang ada;

f. Penerapan respon risiko, proses penerapan strategi reposn risiko terhadap risiko;

g. Monitoring risiko, proses mengawasi penerapan respon risiko, penelusuran risiko teridentifikasi, identifikasi dan menganalisis risiko baru, dan mengevaluasi efektifitas proses risiko selama proyek.

Setiap tahapan manajemen risiko memiliki proses yang melibatkan input, teknik proses, output yang ditunjukkan pada Gambar 3.

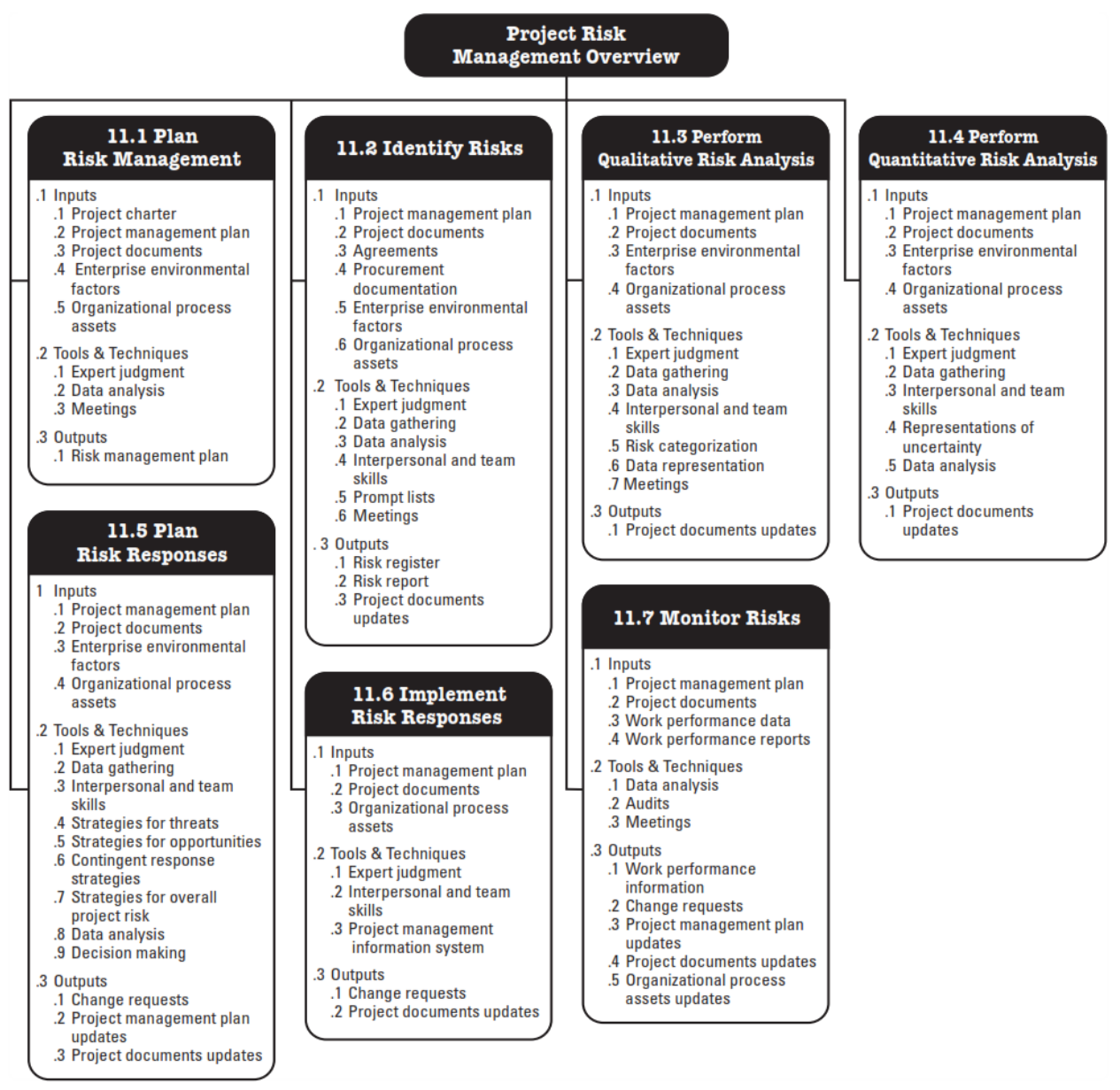

\section{Gambar 3. Tahapan Proses Manajemen Risiko Proyek}

(Project Management Institute, 2017) 
Analisis perbandingan manajemen risiko dilakukan pada penelitian ini dilakukan pada 2 tahapan manajemen risiko, yaitu pada tahapan identifikasi risiko, dan tahapan perencanaan respons terhadap risiko.

\subsubsection{Identifikasi Risiko}

Proses identifikasi risiko merupakan tahapan awal dari manajemen risiko dimana proses mengidentifikasi risiko proyek individu yang merupakan sumber risiko proyek. Tahapan identifikasi risiko secara umum terdapat 2 tingkatan dalam proyek, yaitu: (Project Management Institute, 2017)

a. Risiko individu, merupakan kejadian atau kondisi yang pada saat terjadi memiliki pengaruh posditif dan negatif pada satu ataupun lebih tujuan dari proyek;

b. Risiko umum proyek, merupakan pengaruh dari ketidakpastian proyek secara keseluruhan, bersumber dari seluruh ketidakpastian, termasuk risiko individu, yang menyebabkan perubahan pada proyek baik bersifat positif maupun negatif.

Tingkat risiko sangat berkaitan erat dengan hirarki tahapan proses konstruksi. Hirarki proses konstruksi secara berurutan terdiri dari organizational (organisasi), project (proyek), activity (aktivitas), operation (operasi), process (proses), dan work task (tugas) (Halpin, 1992) ditunjukkan pada Gambar 4.

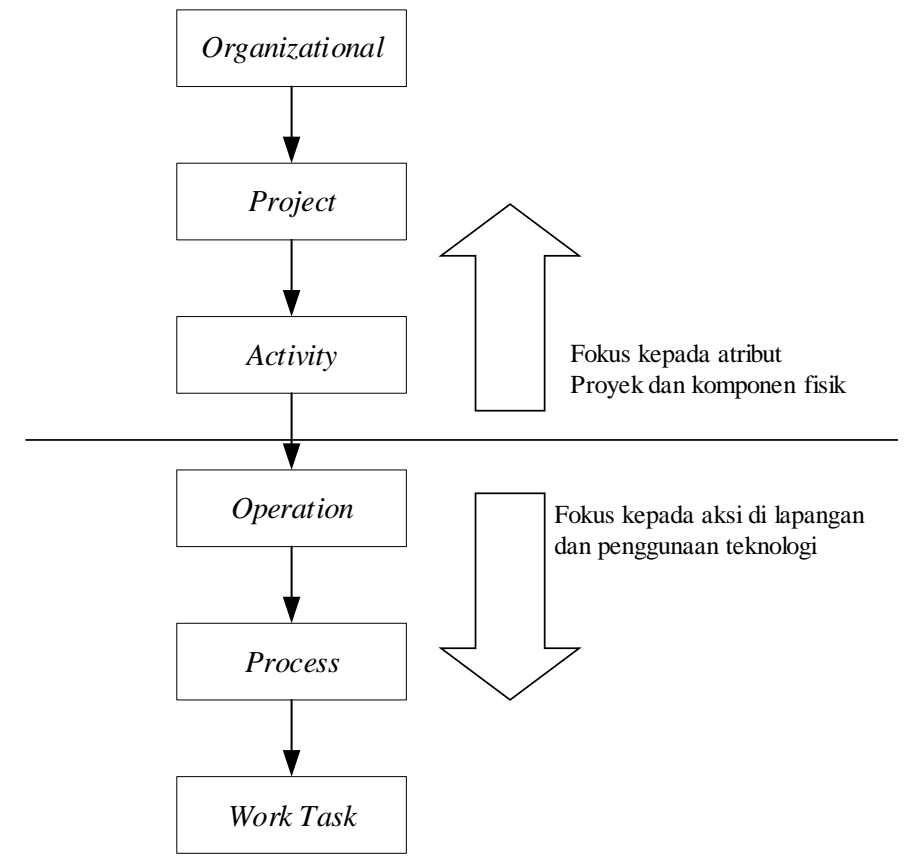

Gambar 4. Hirarki Proses Konstruksi (Halpin, 1992) 
Pada setiap tingkat hirarki konstruksi, memiliki proses yang spesifik sesuai tingkatannya. Berikut proses pada setiap tingkatan proses konstruksinya (Halpin, 1992):

a. Organizational, tingkat proses konstruksi yang berfokus pada aspek legal dan struktur bisnis perusahaan, dan berbagai fungsi manajemen yang dikerjakan oleh interaksi antara kantor pusat dan perwakilan di proyek kosntruksi;

b. Project, tingkat proses konstruksi yang berfokus pada pengendalian jadwal dan biaya;

c. Activity, tingkat proses konstruksi yang berfokus pada atirbut sumber daya proyek yang penurunan dari project.

d. Operation, tingkat proses konstruksi yang berfokus pada teknologi dan detail bagaimana konstruksi berjalan;

e. Task, tingkat proses konstruksi yang berfokus pada identifikasi porsi tugas pekerja di lapangan.

Sementara dari faktor internal dan eksternal, risiko proyek konstruksi dapat dikelompokkan menjadi (Prabawani, 2012):

a. Risiko operasional, risiko yang bersala dari tingkat operasional perusahaan. Sebagai contoh adalah risiko proses kerja, teknologi, sumber daya, perijinan, dan kebijakan regulator;

b. Risiko finansial, risiko yang berdampak pada keuangan perusahaan. Sebagai contoh adalah risiko kredit, likuiditas, inflasi, cost overrun, dan pasar;

c. Risiko hazard, risiko yang berhubungan dengan kecelakaan fisik. Sebagai contoh stabilitas politik, dan force majrure.

d. Risiko strategis, risiko yang disebabkan kesalahan keputusan strategis perusahaan yang tidak sesuai dengan lingkungan perusahaan. Sebagai contoh adalah risiko kompetisi, dan joint venture.

Pada penelitian ini, perbandingan karakteristik identifikasi risiko dilakukan analisis pada risiko-risiko yang di identifikasi oleh semua perusahaan kontraktor yang menjadi studi kasus yang dikalsifikasikan pada 4 kelompok risiko hasil studi literatur. Sedangkan pada tingkat risiko pada hirarki proses konstruksi, pada penlitian ini akan berfokus pada tingkat organizational dan project.

\subsubsection{Perencanaan Respon Terhadap Risiko}

Tahapan perencanan respon terhadap risiko dilakukan sebagai salah satu langkah mitigasi terhdap risiko yang telah diidentifikasi dan dianalisis pada tahapan manajemen risiko sebelumnya. Pada perencanaan respon risiko, terdapat strategi untuk menghadapi 
risiko yang bersifat ancanman dan risiko yang bersifat peluang. Berikut beberapa strategi yang dapat dilakukan untuk menghadapi risiko yang bersifat ancaman (Project Management Institute, 2017):

a. Escalate, strategi respon terhadap risiko ancaman yang dilakukan berupa ekslasi penanganan risiko, ketika tim proyek menyetujui bahwa respon terhadap risiko yang dihadapi akan melebihi otoritas pada tingkat proyek, sehingga perlu dieskalasi untuk otoritas yang lebih tinggi;

b. Avoid, strategi respon terhadap risiko ancaman berupa penghindaran risiko untuk melindungi proyek dari risiko yang diidentifikasi, sebagi contoh memperpanjang jadwal, merubah strategi proyek, atau mengurangi lingkup proyek;

c. Transfer, strategi respon terhadap risiko ancaman berupa melimpahkan kepemilikan risiko ancaman kepada pihak ketiga untuk mengelola risiko dengan menanggung risiko jika ancaman risiko yang dihadapi terjadi, sebagai contoh melimpahkan asuransi, jaminan kinerja, pada pihak ketiga;

d. Mitigate, strategi respon terhadap risiko ancaman berupa mitigasi risiko, dimana upaya mengurangi probabilitas kejadian risiko atau mengurangi dampak risiko, sebagai contoh desain redundansi pada sistem untuk mengurangi dampak kerusakan;

e. Accept, strategi respon terhadap risiko ancaman berupa menerima risiko yang terjadi, biasanya pada ancaman risiko yang rendah.

Berikut beberapa strategi yang dapat dilakukan untuk menghadapi risiko yang bersifat peluang (Project Management Institute, 2017):

a. Escalate, respon terhadap risiko peluang berupa ekslasi penanganan risiko, ketika tim proyek menyetujui bahwa respon terhadap risiko yang dihadapi akan melebihi otoritas pada tingkat proyek, sehingga perlu dieskalasi untuk otoritas yang lebih tinggi;

b. Exploit, respon terhadap risiko peluang berupa memanfaatkan secara fokus risiko peluang agar dapat dimanfaatkan untuk keuntungan perusahaan pada prioritas risiko peluang yang tinggi, sebagai contoh adalah strategi mereduksi jadwal pekerjaan dengan berbagai teknologi dengan tujuan peluang risiko adalah mereduksi biaya;

c. Share, respon terhadap risiko peluang berupa berbagi kepemilikan risiko peluang kepada pihak ketiga untuk berbagi keuntungan jika risiko peluang terjadi, sebagi contoh adalah strategi joint venture; 
d. Enhance, respon terhadap risiko peluang berupa upaya meningkatkan probabilitas atau dampak dari risiko peluang, sebagai contoh adalah strategi menambah sumber daya untuk menyelesaikan proyek lebih cepat;

e. Accept, respon terhadap risiko peluang berupa menerima risiko peluang menerima risiko yang terjadi, biasanya pada risiko peluang yang rendah.

Pada penelitian ini, perbandingan karakteristik identifikasi risiko dilakukan analisis pada kelompok-kelompok risiko yang di identifikasi oleh semua perusahaan kontraktor yang menjadi studi kasus pada annual report rentang waktu 2014-2018. Sementara perbandingan respon terhadap risiko, diidentifikasi juga respons terhadap risiko pada annual report rentang waktu 2014-2018.

\section{Metodologi Penelitian}

Metodologi penelitian yang digunakan pada penelitian ini adalah simple kualitatif comparisson (perbandingan kualitatif sederhana) pada 8 studi kasus kontraktor BUMN dan kontraktor swasta. Kontraktor BUMN dan kontraktor swasta yang dipilih dari total 17 kontraktor yang telah melakukan IPO ditunjukkan pada Tabel 4. Data identifikasi risiko dan perencanaa terhadap risiko didapat melalui data sekunder, yaitu berdasarkan dokumen manajemen risiko yang tertulis pada annual report (laporan tahunan) perusahaan. Data identifikasi risiko dan perencanaa terhadap risiko yang tercantum dalam annual report secara umum merupakan top risk yang dihadapi oleh perusahaan.

Tabel 4. Studi Kasus Penelitian

\begin{tabular}{ccc}
\hline $\begin{array}{c}\text { Kode Studi } \\
\text { Kasus }\end{array}$ & Kontraktor & $\begin{array}{c}\text { Status } \\
\text { Perusahaan }\end{array}$ \\
\hline $\mathrm{A}$ & PT Wijaya Karya (Persero) Tbk. (WIKA) & BUMN \\
\hline $\mathrm{B}$ & PT Waskita Karya (Persero) Tbk. (WSKT) & BUMN \\
\hline $\mathrm{C}$ & PT PP (Persero) Tbk. (PTPP) & BUMN \\
\hline $\mathrm{D}$ & PT Adhi Karya (Persero) Tbk. (ADHI) & BUMN \\
\hline $\mathrm{W}$ & PT Acset Indonusa Tbk. (ACST) & Swasta \\
\hline $\mathrm{X}$ & PT Nusa Konstruksi Enjiniring Tbk. (DGIK) & Swasta \\
\hline $\mathrm{Y}$ & PT Total Bangun Persada Tbk. (TOTL) & Swasta \\
\hline $\mathrm{Z}$ & PT Jaya Konstruksi Manggala Pratama Tbk. (JKON) & Swasta \\
\hline
\end{tabular}

\section{Hasil Analisis Data}

Analisis perbandingan identifikasi risiko dan perencanaan respon terhadap risiko dilakukan pada 4 kelompok besar risiko hasil studi literatur, yaitu risiko finansial, risiko 
operasional, risiko strategi, dan risiko hazard. Sementara analisis perbandingan perencanan respon terhadap risiko dilakukan berdasarkan 5 karakteristik respon terhadap ancaman risiko, yaitu escalate, avoid, transfer, mitigate, dan accept. Analisis perbandingan dimulai dari hasil perbandingan identifikasi risiko dilanjutkan dengan hasil perbandingan perencanaan respon terhadap risiko. Berikut hasil analisis yang dilakukan.

\subsection{Risiko Finansial}

Pada kelompok risiko finansial, diidentifikasi 2 sub-kelompok risiko, yaitu subkelompok risiko pendanaan dan sub-kelompok risiko ekonomi. Pada sub-kelompok risiko pendanaan, diidentifikasi 5 risiko yang diidentifikasi oleh kontraktor sebagai top risk yang dihadapi perusahaan ditunjukkan pada Tabel 5. Sementara pada sub-kelompok risiko ekonomi diidentifikasi 5 risiko yang diidentifikasi oleh kontraktor sebagai top risk yang dihadapi perusahaan ditunjukkan pada Tabel 6 .

Tabel 5. Indentifikasi Risiko Finansial - Pendanaan

\begin{tabular}{|c|c|c|c|c|c|c|c|c|}
\hline \multirow{3}{*}{$\begin{array}{l}\text { Kode } \\
\text { Risiko }\end{array}$} & \multirow{3}{*}{ Identifikasi Risiko } & \multicolumn{7}{|c|}{ Kontraktor } \\
\hline & & \multicolumn{4}{|c|}{ BUMN } & \multicolumn{3}{|c|}{ Swasta } \\
\hline & & $\mathbf{A}$ & $\mathbf{B}$ & $\mathbf{C}$ & $\mathbf{D}$ & $\mathbf{W}$ & $\mathbf{X}$ & $\mathbf{Y}$ \\
\hline F1 & Defisit cash flow & $\checkmark$ & & $\checkmark$ & & & & $\checkmark$ \\
\hline $\mathrm{F} 2$ & Likuiditas (pembayaran / piutang tertunda) & & $\checkmark$ & $\checkmark$ & $\checkmark$ & $\checkmark$ & $\checkmark$ & $\checkmark \checkmark \checkmark$ \\
\hline F3 & Kredit & $\checkmark$ & $\checkmark$ & & & & $\checkmark$ & \\
\hline F4 & Pelaporan pajak & & $\checkmark$ & & & & & $\checkmark$ \\
\hline F5 & Denda proyek & & & & & $\checkmark$ & & \\
\hline
\end{tabular}

Tabel 6. Indentifikasi Risiko Finansial - Ekonomi

\begin{tabular}{|c|c|c|c|c|c|c|c|c|c|}
\hline \multirow{3}{*}{$\begin{array}{l}\text { Kode } \\
\text { Risiko }\end{array}$} & \multirow{3}{*}{ Identifikasi Risiko } & \multicolumn{8}{|c|}{ Kontraktor } \\
\hline & & \multicolumn{4}{|c|}{ BUMN } & \multicolumn{4}{|c|}{ Swasta } \\
\hline & & $\mathbf{A}$ & $\mathbf{B}$ & $\mathbf{C}$ & D & $\mathbf{W}$ & $\mathbf{X}$ & $\mathbf{Y}$ & $\mathbf{Z}$ \\
\hline E1 & Fluktuasi nilai tukar mata uang & $\checkmark$ & $\checkmark$ & $\checkmark$ & $\checkmark$ & & $\checkmark$ & $\checkmark$ & $\checkmark$ \\
\hline E2 & Tingkat suku bunga naik & & $\checkmark$ & $\checkmark$ & & & $\checkmark$ & $\checkmark$ & $\checkmark$ \\
\hline E3 & Perubahan kondisi ekonomi / inflasi & & $\checkmark$ & & & $\checkmark$ & & $\checkmark$ & $\checkmark$ \\
\hline E4 & Kenaikan harga material & & $\checkmark$ & & & $\checkmark$ & $\checkmark$ & $\checkmark$ & $\checkmark$ \\
\hline E5 & Kenaikan biaya konstruksi & & $\checkmark$ & & & & $\checkmark$ & $\checkmark$ & $\checkmark$ \\
\hline
\end{tabular}

Dari hasil analisis perbandingan identifikasi risiko, berikut dianalisis perbandingan analisis perbandingan perencanaan respon terhadap risiko ditunjukkan pada 0 dan Tabel 8. 
Tabel 7. Respon Terhadap Risiko Finansial - Pendanaan

\begin{tabular}{|c|c|c|c|c|c|c|c|c|c|c|c|}
\hline \multirow{3}{*}{$\begin{array}{l}\text { Kode } \\
\text { Respon }\end{array}$} & \multirow{3}{*}{$\begin{array}{l}\text { Kode } \\
\text { Risiko }\end{array}$} & \multirow{3}{*}{$\begin{array}{c}\text { Tipe } \\
\text { Respon }\end{array}$} & \multirow{3}{*}{$\begin{array}{c}\text { Respon Terhadap } \\
\text { Risiko }\end{array}$} & \multicolumn{8}{|c|}{ Kontraktor } \\
\hline & & & & \multicolumn{4}{|c|}{ BUMN } & \multicolumn{4}{|c|}{ Swasta } \\
\hline & & & & $\mathbf{A}$ & B & $\mathbf{C}$ & D & $\mathbf{W}$ & $\mathbf{X}$ & $\mathbf{Y}$ & $\mathbf{Z}$ \\
\hline FR1 & $\mathrm{F} 1$ & Mitigate & $\begin{array}{c}\text { Melakukan kebijakkan } \\
\text { perusahaan pengawasan } \\
\text { cash flow proyek }\end{array}$ & $\checkmark$ & & $\checkmark$ & & & & & \\
\hline FR2 & $\mathrm{F} 1$ & Mitigate & $\begin{array}{l}\text { Monitoring cash flow } \\
\text { proyek agar tetap positif }\end{array}$ & & & & & & & $\checkmark$ & \\
\hline FR3 & $\mathrm{F} 1$ & Mitigate & $\begin{array}{l}\text { Melakukan perjanjian } \\
\text { dengan vendor untuk } \\
\text { melakukan waktu } \\
\text { pembayaran secara back } \\
\text { to back. }\end{array}$ & & & $\checkmark$ & & & & & \\
\hline FR4 & $\mathrm{F} 2$ & Mitigate & $\begin{array}{l}\text { Monitoring dan } \\
\text { menganalisis piutang } \\
\text { perusahaan }\end{array}$ & & $\checkmark$ & $\checkmark$ & $\checkmark$ & $\checkmark$ & $\checkmark$ & $\checkmark$ & $\checkmark$ \\
\hline FR5 & F2 & Avoid & $\begin{array}{c}\text { Memperlambat } \\
\text { pekerjaan hingga } \\
\text { menempuh jalur hukum } \\
\text { untuk keterlambatan } \\
\text { pembayaran }\end{array}$ & & & & $\checkmark$ & & & $\checkmark$ & \\
\hline FR6 & $\mathrm{F} 3$ & Mitigate & $\begin{array}{c}\text { Ketersediaan plafon } \\
\text { pada fasilitas Perbankan }\end{array}$ & & $\checkmark$ & $\checkmark$ & & & & & \\
\hline FR7 & F3 & Mitigate & $\begin{array}{c}\text { Mengupayakan } \\
\text { (sebagian) pinjaman } \\
\text { sebagai pinjaman jangka } \\
\text { panjang dengan tingkat } \\
\text { suku bunga tetap }\end{array}$ & & & & & & $\checkmark$ & & \\
\hline FR8 & $\mathrm{F} 4$ & Mitigate & $\begin{array}{l}\text { Monitoring peraturan } \\
\text { dan progres pelaporan } \\
\text { pajak sesuai peraturan } \\
\text { dengan konsultan pajak }\end{array}$ & & $\checkmark$ & & & & $\checkmark$ & & \\
\hline
\end{tabular}


Tabel 8. Respon Terhadap Risiko Finansial - Ekonomi

\begin{tabular}{|c|c|c|c|c|c|c|c|c|c|c|c|}
\hline \multirow{3}{*}{$\begin{array}{l}\text { Kode } \\
\text { Respon }\end{array}$} & \multirow{3}{*}{$\begin{array}{l}\text { Kode } \\
\text { Risiko }\end{array}$} & \multirow{3}{*}{$\begin{array}{l}\text { Tipe } \\
\text { Respon }\end{array}$} & \multirow{3}{*}{ Identifikasi Risiko } & \multicolumn{8}{|c|}{ Kontraktor } \\
\hline & & & & \multicolumn{4}{|c|}{ BUMN } & \multicolumn{4}{|c|}{ Swasta } \\
\hline & & & & $\mathbf{A}$ & B & $\mathbf{C}$ & D & $\mathbf{W}$ & $\mathbf{X}$ & $\mathbf{Y}$ & $\mathbf{Z}$ \\
\hline ER1 & E1 & Mitigate & $\begin{array}{c}\text { Melakukan perjanjian } \\
\text { dengan vendor } \\
\text { untuk melakukan } \\
\text { pembayaran secara } \\
\text { back to back sesuai dengan } \\
\text { mata uang } \\
\text { dalam kontrak induk. }\end{array}$ & & $\checkmark$ & $\checkmark$ & & & & & \\
\hline ER2 & E1 & Mitigate & $\begin{array}{c}\text { Perusahaan mempunyai } \\
\text { work instruction tentang } \\
\text { transaksi lindung nilai } \\
\text { (hedging) }\end{array}$ & & & $\checkmark$ & $\checkmark$ & & $\checkmark$ & & \\
\hline ER3 & E1 & Mitigate & $\begin{array}{l}\text { Menyamakan denominasi } \\
\text { kewajiban pembayaran } \\
\text { kepada pihak ketiga dengan } \\
\text { denominasi pembayaran } \\
\text { termin pekerjaan. }\end{array}$ & & & & $\checkmark$ & & & & \\
\hline ER4 & E1 & Mitigate & $\begin{array}{l}\text { Menetapkan sebagian fee } \\
\text { dalam denominasi dollar }\end{array}$ & & & & & & $\checkmark$ & & \\
\hline ER5 & E1 & Mitigate & $\begin{array}{l}\text { Monitoring fluktuasi mata } \\
\text { uang asing terhadap rupiah }\end{array}$ & $\checkmark$ & & & & & & $\checkmark$ & $\checkmark$ \\
\hline ER6 & E2 & Mitigate & $\begin{array}{l}\text { Pengawasan terhadap } \\
\text { dampak kenaikan suku } \\
\text { bunga dipasar untuk } \\
\text { meminimalisasi dampak } \\
\text { negatif terhadap perseroan. }\end{array}$ & & $\checkmark$ & $\checkmark$ & & & & $\checkmark$ & $\checkmark$ \\
\hline & E3 & Mitigate & $\begin{array}{l}\text { Mendesain cash flow mata } \\
\text { uang asing yang } \\
\text { menyesuaikan dengan } \\
\text { kebutuhan material import }\end{array}$ & & $\checkmark$ & & & & & & \\
\hline
\end{tabular}


Tabel 8. Respon Terhadap Risiko Finansial - Ekonomi (lanjutan)

\begin{tabular}{|c|c|c|c|c|c|c|c|c|c|c|c|}
\hline \multirow{3}{*}{$\begin{array}{l}\text { Kode } \\
\text { Respon }\end{array}$} & \multirow{3}{*}{$\begin{array}{l}\text { Kode } \\
\text { Risiko }\end{array}$} & \multirow{3}{*}{$\begin{array}{c}\text { Tipe } \\
\text { Respon }\end{array}$} & \multirow{3}{*}{ Identifikasi Risiko } & \multicolumn{8}{|c|}{ Kontraktor } \\
\hline & & & & \multicolumn{4}{|c|}{ BUMN } & \multicolumn{4}{|c|}{ Swasta } \\
\hline & & & & $\mathbf{A}$ & $\mathbf{B}$ & $\mathbf{C}$ & D & $\mathbf{W}$ & $\mathbf{X}$ & $\mathbf{Y}$ & $\mathbf{Z}$ \\
\hline ER8 & E3 & Mitigate & $\begin{array}{l}\text { Menganalisis calon proyek } \\
\text { yang bermasalaha untuk } \\
\text { tidak ditanganai }\end{array}$ & & & $\checkmark$ & & & & & \\
\hline ER9 & E3 & Mitigate & Mencari pangsa pasar baru & & & & & $\checkmark$ & & $\checkmark$ & $\checkmark$ \\
\hline E10 & E3 & Escalate & $\begin{array}{l}\text { Menjadi tanggung jawab } \\
\text { Dewan Komisaris dan } \\
\text { Direksi yang telah } \\
\text { membangun kerangka } \\
\text { manajemen risiko yang } \\
\text { sesuai. }\end{array}$ & & & & $\checkmark$ & & & & \\
\hline E11 & E4 & Mitigate & $\begin{array}{c}\text { Melakukan kontrak payung } \\
\text { material strategis }\end{array}$ & & & $\checkmark$ & & $\checkmark$ & $\checkmark$ & $\checkmark$ & $\checkmark$ \\
\hline E12 & E5 & Mitigate & $\begin{array}{c}\text { Estimasi perkiraan kenaikan } \\
\text { harga }\end{array}$ & & & & & $\checkmark$ & & & \\
\hline
\end{tabular}

\subsection{Risiko Operasional}

Pada kelompok risiko operasional, diidentifikasi 3 sub-kelompok risiko, yaitu sub-kelompok risiko sumber daya manusia, sub-kelompok risiko aspek legal, dan subkelompok risiko aspek teknis. Pada sub-kelompok risiko sumber daya manusia, diidentifikasi 3 risiko yang diidentifikasi oleh kontraktor sebagai top risk yang dihadapi perusahaan ditunjukkan pada Tabel 9. Pada sub-kelompok risiko aspek legal, diidentifikasi 4 risiko yang diidentifikasi oleh kontraktor sebagai top risk yang dihadapi perusahaan ditunjukkan pada 0 . Sementara pada sub-kelompok risiko aspek teknis diidentifikasi 9 risiko yang diidentifikasi oleh kontraktor sebagai top risk yang dihadapi perusahaan ditunjukkan pada Tabel 11. 
Tabel 9. Indentifikasi Risiko Operasional - Sumber Daya Manusia

\begin{tabular}{cccccccccc}
\hline \multirow{2}{*}{$\begin{array}{c}\text { Kode } \\
\text { Risiko }\end{array}$} & \multirow{3}{*}{ Identifikasi Risiko } & \multicolumn{9}{c}{ Kontraktor } \\
\cline { 3 - 9 } & & \multicolumn{4}{c}{ BUMN } & \multicolumn{5}{c}{ Swasta } \\
\cline { 3 - 9 } S1 & Supply jumlah SDM (Quantity) & $\checkmark$ & $\checkmark$ & $\checkmark$ & $\checkmark$ & $\checkmark$ & & $\checkmark$ & $\checkmark$ \\
\hline S2 & Supply SDM berkualitas (Quality) & $\checkmark$ & $\checkmark$ & $\checkmark$ & $\checkmark$ & $\checkmark$ & & $\checkmark$ & $\checkmark$ \\
\hline S3 & Pengunduran karyawan kunci & $\checkmark$ & & & & $\checkmark$ & & \\
\hline
\end{tabular}

Tabel 10. Indentifikasi Risiko Operasional - Aspek Legal

\begin{tabular}{|c|c|c|c|c|c|c|c|c|}
\hline \multirow{3}{*}{$\begin{array}{c}\text { Kode } \\
\text { Risiko }\end{array}$} & \multirow{3}{*}{ Identifikasi Risiko } & \multicolumn{7}{|c|}{ Kontraktor } \\
\hline & & \multicolumn{4}{|c|}{ BUMN } & \multicolumn{3}{|c|}{ Swasta } \\
\hline & & $\mathbf{A}$ & B & $\mathbf{C}$ & $\mathbf{D}$ & $\mathbf{W}$ & $\mathbf{Y}$ & $\mathbf{Z}$ \\
\hline L1 & Perubahan kebijakan pemerintah & $\checkmark$ & $\checkmark$ & $\checkmark$ & $\checkmark$ & $\checkmark$ & $\checkmark$ & \\
\hline L2 & $\begin{array}{l}\text { Sengketa (kontrak, lahan, } \\
\text { tuntutan pihak ke-3) }\end{array}$ & $\checkmark$ & $\checkmark$ & $\checkmark$ & $\checkmark$ & $\checkmark$ & $\checkmark$ & \\
\hline L3 & Pengurusan IMB dan AMDAL & & & $\checkmark$ & & & & \\
\hline L4 & Perbedaan regulasi di luar negri & & & & $\checkmark$ & & & \\
\hline
\end{tabular}

Tabel 11. Indentifikasi Risiko Operasional - Aspek Teknis

\begin{tabular}{|c|c|c|c|c|c|c|c|c|}
\hline \multirow{3}{*}{$\begin{array}{l}\text { Kode } \\
\text { Risiko }\end{array}$} & \multirow{3}{*}{ Identifikasi Risiko } & \multicolumn{7}{|c|}{ Kontraktor } \\
\hline & & \multicolumn{4}{|c|}{ BUMN } & \multicolumn{3}{|c|}{ Swasta } \\
\hline & & $\mathbf{A}$ & $\mathbf{B}$ & $\mathbf{C}$ & $\mathbf{D}$ & $\mathbf{W}$ & $\mathbf{X}$ & $\mathbf{Y}$ \\
\hline $\mathrm{T} 1$ & $\begin{array}{l}\text { Pemilihan mitra/partner (sub- } \\
\text { kontraktor, tenaga ahli) }\end{array}$ & $\checkmark$ & & $\checkmark$ & $\checkmark$ & $\checkmark$ & $\checkmark$ & $\checkmark$ \\
\hline $\mathrm{T} 2$ & Desain/FS/spesifikasi tidak valid & $\checkmark$ & & $\checkmark$ & $\checkmark$ & & & \\
\hline $\mathrm{T} 3$ & Keterlambatan proyek & $\checkmark$ & $\checkmark$ & $\checkmark$ & & $\checkmark$ & $\checkmark$ & $\checkmark$ \\
\hline $\mathrm{T} 4$ & Kesulitan supply material & $\checkmark$ & $\checkmark$ & $\checkmark$ & $\checkmark$ & $\checkmark$ & & $\checkmark$ \\
\hline T5 & Kualitas mutu proyek & & & $\checkmark$ & & & $\checkmark$ & $\checkmark$ \\
\hline T6 & $\begin{array}{c}\text { Kondisi tanah \& kondisi alam yang tak } \\
\text { terprediksi }\end{array}$ & & $\checkmark$ & $\checkmark$ & $\checkmark$ & & & \\
\hline $\mathrm{T} 7$ & Kenterbatasan \& kerusakan peralatan & & & $\checkmark$ & $\checkmark$ & $\checkmark$ & $\checkmark$ & $\checkmark$ \\
\hline $\mathrm{T} 8$ & Proyek di lokasi baru & & & & & $\checkmark$ & & \\
\hline T9 & Kepuasan pelanggan & & & & & & & $\checkmark$ \\
\hline
\end{tabular}

Dari hasil analisis perbandingan identifikasi risiko, berikut dianalisis perbandingan analisis perbandingan perencanaan respon terhadap risiko ditunjukkan pada Tabel 12, Tabel 13, dan Tabel 14. 
Tabel 12. Respon Terhadap Risiko Operasional - Sumber Daya Manusia

\begin{tabular}{|c|c|c|c|c|c|c|c|c|c|c|c|}
\hline \multirow{3}{*}{$\begin{array}{l}\text { Kode } \\
\text { Respon }\end{array}$} & \multirow{3}{*}{$\begin{array}{l}\text { Kode } \\
\text { Risiko }\end{array}$} & \multirow{3}{*}{$\begin{array}{c}\text { Tipe } \\
\text { Respon }\end{array}$} & \multirow{3}{*}{$\begin{array}{c}\text { Respon Terhadap } \\
\text { Risiko }\end{array}$} & \multicolumn{8}{|c|}{ Kontraktor } \\
\hline & & & & \multicolumn{4}{|c|}{ BUMN } & \multicolumn{4}{|c|}{ Swasta } \\
\hline & & & & $\mathbf{A}$ & B & $\mathbf{C}$ & D & $\mathbf{W}$ & $\mathbf{X}$ & $\mathbf{Y}$ & $\mathbf{Z}$ \\
\hline SR1 & $\mathrm{S} 1$ & Mitigate & $\begin{array}{c}\text { Melakukan } \\
\text { perekrutan secara } \\
\text { terpusat }\end{array}$ & $\checkmark$ & $\checkmark$ & $\checkmark$ & $\checkmark$ & $\checkmark$ & & $\checkmark$ & $\checkmark$ \\
\hline SR2 & S2 & Mitigate & $\begin{array}{c}\text { Melakukan } \\
\text { pelatihan karyawan }\end{array}$ & $\checkmark$ & $\checkmark$ & $\checkmark$ & $\checkmark$ & $\checkmark$ & & $\checkmark$ & $\checkmark$ \\
\hline SR3 & S2 & Avoid & $\begin{array}{c}\text { Melakukan seleksi } \\
\text { karyawan yang } \\
\text { ketat }\end{array}$ & & & & & $\checkmark$ & & $\checkmark$ & $\checkmark$ \\
\hline SR4 & S3 & Mitigate & $\begin{array}{l}\text { Membuat sistem } \\
\text { jenjang karir } \\
\text { pegawai yang baik }\end{array}$ & & & & & $\checkmark$ & & & \\
\hline
\end{tabular}

Tabel 13. Respon Terhadap Risiko Operasional - Aspek Legal

\begin{tabular}{|c|c|c|c|c|c|c|c|c|c|c|}
\hline \multirow{3}{*}{$\begin{array}{c}\text { Kode } \\
\text { Respon }\end{array}$} & \multirow{3}{*}{$\begin{array}{l}\text { Kode } \\
\text { Risiko }\end{array}$} & \multirow{3}{*}{$\begin{array}{c}\text { Tipe } \\
\text { Respon }\end{array}$} & \multirow{3}{*}{$\begin{array}{c}\text { Respon Terhadap } \\
\text { Risiko }\end{array}$} & \multicolumn{7}{|c|}{ Kontraktor } \\
\hline & & & & \multicolumn{4}{|c|}{ BUMN } & \multicolumn{3}{|c|}{ Swasta } \\
\hline & & & & $\mathbf{A}$ & B & $\mathbf{C}$ & D & $\mathbf{W}$ & $\mathbf{X}$ & $\mathbf{Y}$ \\
\hline LR1 & L1 & Mitigate & $\begin{array}{c}\text { Monitoring } \\
\text { perkembangan } \\
\text { pemerintah }\end{array}$ & $\checkmark$ & $\checkmark$ & $\checkmark$ & $\checkmark$ & & & \\
\hline LR2 & $\mathrm{L} 1$ & Accept & $\begin{array}{l}\text { Menerima perubahan } \\
\text { kebijakan pemerintah }\end{array}$ & $\checkmark$ & $\checkmark$ & $\checkmark$ & $\checkmark$ & $\checkmark$ & & $\checkmark$ \\
\hline LR3 & $\mathrm{L} 1$ & Mitigate & $\begin{array}{c}\text { Menganalisis kembali } \\
\text { keputusan investasi }\end{array}$ & $\checkmark$ & $\checkmark$ & $\checkmark$ & $\checkmark$ & & & \\
\hline LR4 & $\mathrm{L} 2$ & Mitigate & $\begin{array}{c}\text { Melakukan analisis lebih } \\
\text { cermat pada pasal-pasal } \\
\text { kontrak dengan tim } \\
\text { sendiri ataupun tenaga } \\
\text { ahli } \\
\end{array}$ & $\checkmark$ & $\checkmark$ & $\checkmark$ & $\checkmark$ & $\checkmark$ & & $\checkmark$ \\
\hline LR5 & $\mathrm{L} 2$ & Mitigate & $\begin{array}{l}\text { Membuat kebijakkan } \\
\text { terkait standar kontrak }\end{array}$ & $\checkmark$ & $\checkmark$ & $\checkmark$ & $\checkmark$ & $\checkmark$ & & $\checkmark$ \\
\hline LR6 & L2 & Mitigate & Melakukan negosiasi & $\checkmark$ & $\checkmark$ & $\checkmark$ & $\checkmark$ & $\checkmark$ & & $\checkmark$ \\
\hline LR7 & $\mathrm{L} 2$ & Transfer & $\begin{array}{c}\text { Asuransi liabilitas pihak } \\
\text { ketiga }\end{array}$ & & & & & & $\checkmark$ & \\
\hline LR8 & L3 & Mitigate & $\begin{array}{l}\text { Menyiapkan tim khusus } \\
\text { perijinan yang handal }\end{array}$ & & & $\checkmark$ & & & & \\
\hline LR9 & L4 & Mitigate & $\begin{array}{c}\text { Memonitoring dan } \\
\text { menyesuaikan regulasi }\end{array}$ & & & & $\checkmark$ & & & \\
\hline
\end{tabular}


Tabel 14. Respon Terhadap Risiko Operasional - Aspek Teknis

\begin{tabular}{|c|c|c|c|c|c|c|c|c|c|c|c|}
\hline \multirow{3}{*}{$\begin{array}{l}\text { Kode } \\
\text { Respon }\end{array}$} & \multirow{3}{*}{$\begin{array}{l}\text { Kode } \\
\text { Risiko }\end{array}$} & \multirow{3}{*}{$\begin{array}{l}\text { Tipe } \\
\text { Respon }\end{array}$} & \multirow{3}{*}{$\begin{array}{c}\text { Respon Terhadap } \\
\text { Risiko }\end{array}$} & \multicolumn{8}{|c|}{ Kontraktor } \\
\hline & & & & \multicolumn{4}{|c|}{ BUMN } & \multicolumn{4}{|c|}{ Swasta } \\
\hline & & & & $\mathbf{A}$ & B & $\mathbf{C}$ & D & $\mathbf{W}$ & $\mathbf{X}$ & $\mathbf{Y}$ & $\mathbf{Z}$ \\
\hline TR1 & $\mathrm{T} 1$ & Avoid & $\begin{array}{c}\text { Selektif dalam } \\
\text { memilih mitra kerja } \\
\text { yang kompeten } \\
\text { dan berpengalaman }\end{array}$ & $\checkmark$ & & $\checkmark$ & $\checkmark$ & $\checkmark$ & $\checkmark$ & $\checkmark$ & \\
\hline TR2 & $\mathrm{T} 1$ & Mitigate & $\begin{array}{l}\text { Melakukan due } \\
\text { diligence (uji } \\
\text { tuntas) dan } \\
\text { persiapan yang } \\
\text { matang }\end{array}$ & & & & $\checkmark$ & $\checkmark$ & & & \\
\hline TR3 & $\mathrm{T} 2$ & Mitigate & $\begin{array}{c}\text { Membangun bank } \\
\text { data terkait analisa } \\
F S \text { yang telah } \\
\text { dilakukan }\end{array}$ & $\checkmark$ & $\checkmark$ & $\checkmark$ & $\checkmark$ & & & & \\
\hline TR4 & $\mathrm{T} 3$ & Mitigate & $\begin{array}{c}\text { Melakukan } \\
\text { perencanaan dan } \\
\text { monitoring jadwal }\end{array}$ & $\checkmark$ & $\checkmark$ & $\checkmark$ & & $\checkmark$ & $\checkmark$ & $\checkmark$ & \\
\hline TR5 & $\mathrm{T} 3$ & Mitigate & $\begin{array}{l}\text { Mengoptimalkan } \\
\text { utilisasi alat }\end{array}$ & & & & & $\checkmark$ & $\checkmark$ & & \\
\hline TR6 & $\mathrm{T} 4$ & Mitigate & $\begin{array}{c}\text { Kontrak payung } \\
\text { pengadaan material }\end{array}$ & $\checkmark$ & $\checkmark$ & $\checkmark$ & & $\checkmark$ & & $\checkmark$ & \\
\hline TR7 & $\mathrm{T} 4$ & Mitigate & $\begin{array}{c}\text { Mendesign dalam } \\
\text { kontrak bahwa } \\
\text { material import } \\
\text { merupakan material } \\
\text { yang disediakan by } \\
\text { owner }\end{array}$ & $\checkmark$ & & & & & & & \\
\hline TR8 & T5 & Mitigate & $\begin{array}{l}\text { Penyusunan standar } \\
\text { mutu perusahaan }\end{array}$ & & & $\checkmark$ & & & $\checkmark$ & $\checkmark$ & \\
\hline TR9 & T6 & Mitigate & $\begin{array}{c}\text { Pendampingan } \\
\text { konsultan ahli }\end{array}$ & & $\checkmark$ & $\checkmark$ & $\checkmark$ & & & & \\
\hline TR10 & $\mathrm{T} 7$ & Mitigate & $\begin{array}{c}\text { Melakukan } \\
\text { inspeksi, dan } \\
\text { peremajaan alat }\end{array}$ & & & $\checkmark$ & $\checkmark$ & $\checkmark$ & $\checkmark$ & $\checkmark$ & \\
\hline TR11 & $\mathrm{T} 8$ & Mitigate & $\begin{array}{c}\text { Membangun relasi } \\
\text { dengan sub- } \\
\text { kontraktor lokal }\end{array}$ & & & & & $\checkmark$ & & & \\
\hline TR12 & T9 & Mitigate & $\begin{array}{c}\text { Memperkuat proses } \\
\text { Know Your } \\
\text { Costumer }(\text { KYC) } \\
\text { dalam melakukan } \\
\text { seleksi proyek }\end{array}$ & & & & & & & $\checkmark$ & \\
\hline
\end{tabular}




\subsection{Risiko Strategi}

Pada kelompok risiko strategi, diidentifikasi 3 sub-kelompok risiko, yaitu subkelompok risiko persaingan usaha, sub-kelompok sosial dan lingkungan, dan subkelompok risiko sistem perusahaan. Pada sub-kelompok risiko persaingan usaha, diidentifikasi 5 risiko yang diidentifikasi oleh kontraktor sebagai top risk yang dihadapi perusahaan ditunjukkan pada Tabel 15. Pada sub-kelompok risiko sosial dan lingkungan, diidentifikasi 3 risiko yang diidentifikasi oleh kontraktor sebagai top risk yang dihadapi perusahaan ditunjukkan pada Tabel 16. Sementara pada sub-kelompok risiko sistem perusahaan diidentifikasi 3 risiko yang diidentifikasi oleh kontraktor sebagai top risk yang dihadapi perusahaan ditunjukkan pada Tabel 17.

Tabel 15. Indentifikasi Risiko Strategi - Persaingan Usaha

\begin{tabular}{|c|c|c|c|c|c|c|c|c|c|}
\hline \multirow{3}{*}{$\begin{array}{c}\text { Kode } \\
\text { Risiko }\end{array}$} & \multirow{3}{*}{ Identifikasi Risiko } & \multicolumn{8}{|c|}{ Kontraktor } \\
\hline & & \multicolumn{4}{|c|}{ BUMN } & \multicolumn{4}{|c|}{ Swasta } \\
\hline & & $\mathbf{A}$ & $\mathbf{B}$ & $\mathbf{C}$ & $\mathbf{D}$ & $\mathbf{W}$ & $\mathbf{X}$ & $\mathbf{Y}$ & $\mathbf{Z}$ \\
\hline $\mathrm{P} 1$ & $\begin{array}{l}\text { Kompetitif persaingan usaha } \\
\text { (lokal dan asing) }\end{array}$ & $\checkmark$ & $\checkmark$ & $\checkmark$ & $\checkmark$ & $\checkmark$ & $\checkmark$ & $\checkmark$ & $\checkmark$ \\
\hline $\mathrm{P} 2$ & Kalah tender & $\checkmark$ & & $\checkmark$ & $\checkmark$ & & & & \\
\hline P3 & Reputasi & $\checkmark$ & & $\checkmark$ & & $\checkmark$ & & $\checkmark$ & \\
\hline $\mathrm{P} 4$ & Strategi anak perusahaan & & $\checkmark$ & $\checkmark$ & $\checkmark$ & & & $\checkmark$ & \\
\hline P5 & Penurunan jumlah proyek & & & & & $\checkmark$ & & $\checkmark$ & $\checkmark$ \\
\hline
\end{tabular}

Tabel 16. Indentifikasi Risiko Strategi - Sosial dan Lingkungan

\begin{tabular}{|c|c|c|c|c|c|c|c|c|c|}
\hline \multirow{3}{*}{$\begin{array}{l}\text { Kode } \\
\text { Risiko }\end{array}$} & \multirow{3}{*}{ Identifikasi Risiko } & \multicolumn{8}{|c|}{ Kontraktor } \\
\hline & & \multicolumn{4}{|c|}{ BUMN } & \multicolumn{4}{|c|}{ Swasta } \\
\hline & & $\mathbf{A}$ & $\mathbf{B}$ & $\mathbf{C}$ & $\mathbf{D}$ & $\mathbf{W}$ & $\mathbf{X}$ & $\mathbf{Y}$ & $\mathbf{Z}$ \\
\hline K1 & $\begin{array}{l}\text { Kondisi sosial dan budaya lokasi } \\
\text { proyek }\end{array}$ & & $\checkmark$ & $\checkmark$ & & & & $\checkmark$ & \\
\hline $\mathrm{K} 2$ & Kerusakan lingkungan & & $\checkmark$ & $\checkmark$ & & & $\checkmark$ & & \\
\hline K3 & Pembebasan Lahan & & & & & $\checkmark$ & & & \\
\hline
\end{tabular}

Tabel 17. Indentifikasi Risiko Strategi - Sistem Perusahaan

\begin{tabular}{|c|c|c|c|c|c|c|c|c|c|}
\hline \multirow{3}{*}{$\begin{array}{l}\text { Kode } \\
\text { Risiko }\end{array}$} & \multirow{3}{*}{ Identifikasi Risiko } & \multicolumn{8}{|c|}{ Kontraktor } \\
\hline & & \multicolumn{4}{|c|}{ BUMN } & \multicolumn{4}{|c|}{ Swasta } \\
\hline & & $\mathbf{A}$ & $\mathbf{B}$ & $\mathbf{C}$ & D & $\mathbf{W}$ & $\mathbf{X}$ & $\mathbf{Y}$ & $\mathbf{Z}$ \\
\hline M1 & $\begin{array}{l}\text { Inkonsistensi penerapan sistem } \\
\text { manajemen }\end{array}$ & $\checkmark$ & & & & & & & \\
\hline M2 & $\begin{array}{c}\text { Kebocoran data rahasia/ penting } \\
\text { kepada pihak luar }\end{array}$ & $\checkmark$ & & & & & & & \\
\hline M3 & Visi dan misi perusahaan & & & & & & & $\checkmark$ & \\
\hline
\end{tabular}


Dari hasil analisis perbandingan identifikasi risiko, berikut dianalisis perbandingan analisis perbandingan perencanaan respon terhadap risiko ditunjukkan pada Tabel 18, Tabel 19, dan Tabel 20.

Tabel 18. Respon Terhadap Risiko Strategi- Persaingan Usaha

\begin{tabular}{|c|c|c|c|c|c|c|c|c|c|c|}
\hline \multirow{3}{*}{$\begin{array}{l}\text { Kode } \\
\text { Risiko }\end{array}$} & \multirow{3}{*}{$\begin{array}{c}\text { Tipe } \\
\text { Respon }\end{array}$} & \multirow{3}{*}{ Respon Terhadap Risiko } & \multicolumn{8}{|c|}{ Kontraktor } \\
\hline & & & \multicolumn{4}{|c|}{ BUMN } & \multicolumn{4}{|c|}{ Swasta } \\
\hline & & & $\mathbf{A}$ & B & $\mathbf{C}$ & $\mathbf{D}$ & $\mathbf{W}$ & $\mathbf{X}$ & $\mathbf{Y}$ & $\mathbf{Z}$ \\
\hline $\mathrm{P} 1$ & Mitigate & $\begin{array}{l}\text { Menigkatkan kompetensi } \\
\text { perusahaan dengan inovasi } \\
\text { teknologi dan metode kerja }\end{array}$ & $\checkmark$ & $\checkmark$ & $\checkmark$ & $\checkmark$ & $\checkmark$ & $\checkmark$ & $\checkmark$ & $\checkmark$ \\
\hline $\mathrm{P} 1$ & Avoid & $\begin{array}{c}\text { Meminta jaminan jumlah } \\
\text { minimum pemakaian jasa } \\
\text { dari pemerintah untuk } \\
\text { mengurangi risiko } \\
\text { kegagalan pasar. }\end{array}$ & & & & $\checkmark$ & & & & \\
\hline $\mathrm{P} 2$ & Mitigate & $\begin{array}{l}\text { Pembentukan tim tender dan } \\
\text { perencanaan tender dengan } \\
\text { matang }\end{array}$ & $\checkmark$ & & $\checkmark$ & $\checkmark$ & & & & \\
\hline $\mathrm{P} 2$ & Mitigate & $\begin{array}{l}\text { Menggandeng tenaga ahli/ } \\
\text { konsultan }\end{array}$ & & & $\checkmark$ & $\checkmark$ & & & & \\
\hline P3 & Mitigate & $\begin{array}{c}\text { Memperkuat proses Know } \\
\text { Your Costumer }(\text { KYC) }\end{array}$ & $\checkmark$ & & $\checkmark$ & & $\checkmark$ & & $\checkmark$ & \\
\hline $\mathrm{P} 3$ & Mitigate & Menjaga mutu pekerjaan & $\checkmark$ & & & & & & $\checkmark$ & \\
\hline P4 & Mitigate & $\begin{array}{l}\text { Menganalisis lebih matang } \\
\text { investasi pada bidang/ nanak } \\
\text { perusahaan }\end{array}$ & & $\checkmark$ & $\checkmark$ & $\checkmark$ & $\checkmark$ & & $\checkmark$ & \\
\hline P4 & Mitigate & $\begin{array}{l}\text { Menutup investasi pada } \\
\text { anak perusahaan yang } \\
\text { menimbulkan kerugian }\end{array}$ & & $\checkmark$ & $\checkmark$ & & & & $\checkmark$ & \\
\hline P5 & Mitigate & Peningkatan mutu pekerjaan & & & & & $\checkmark$ & $\checkmark$ & $\checkmark$ & \\
\hline P5 & Mitigate & $\begin{array}{l}\text { Mencari alternatif proyek } \\
\text { lain (infrastruktur) }\end{array}$ & & & & & $\checkmark$ & & & \\
\hline P5 & Mitigate & $\begin{array}{c}\text { Melakukan kerjasama } \\
\text { konsorsium atatupun joint } \\
\text { venture untuk mendapatkan } \\
\text { proyek }\end{array}$ & & & & & $\checkmark$ & & & \\
\hline
\end{tabular}


Tabel 19. Respon Terhadap Risiko Strategi- Sosial dan Lingkungan

\begin{tabular}{|c|c|c|c|c|c|c|c|c|c|}
\hline \multirow{3}{*}{$\begin{array}{l}\text { Kode } \\
\text { Respon }\end{array}$} & \multirow{3}{*}{$\begin{array}{l}\text { Kode } \\
\text { Risiko }\end{array}$} & \multirow{3}{*}{$\begin{array}{c}\text { Tipe } \\
\text { Respon }\end{array}$} & \multirow{3}{*}{$\begin{array}{c}\text { Respon } \\
\text { Terhadap Risiko }\end{array}$} & \multicolumn{6}{|c|}{ Kontraktor } \\
\hline & & & & \multicolumn{3}{|c|}{ BUMN } & \multicolumn{3}{|c|}{ Swasta } \\
\hline & & & & $\mathbf{A}$ & B & C D & $\mathbf{W}$ & $\mathbf{X}$ & Y Z \\
\hline KR1 & K1 & Mitigate & $\begin{array}{c}\text { Perusahaan } \\
\text { berkoordinasi dan } \\
\text { bersosialisasi } \\
\text { dengan } \\
\text { masyarakat dan } \\
\text { aparat }\end{array}$ & & $\checkmark$ & $\checkmark$ & & & $\checkmark$ \\
\hline KR2 & $\mathrm{K} 2$ & Mitigate & $\begin{array}{c}\text { Perusahaan } \\
\text { menetapkan } \\
\text { standar kualitas } \\
\text { lingkungan kerja }\end{array}$ & & $\checkmark$ & $\checkmark$ & & $\checkmark$ & \\
\hline KR3 & K3 & Accept & $\begin{array}{c}\text { Menerima risiko, } \\
\text { karena } \\
\text { pembebasan } \\
\text { lahan merupakan } \\
\text { bagian dari } \text { owner }\end{array}$ & & & & $\checkmark$ & & \\
\hline
\end{tabular}

Tabel 20. Respon Terhadap Risiko Strategi- Sistem Perusahaan

\begin{tabular}{|c|c|c|c|c|c|c|c|c|c|c|c|}
\hline \multirow{3}{*}{$\begin{array}{l}\text { Kode } \\
\text { Respon }\end{array}$} & \multirow{3}{*}{$\begin{array}{l}\text { Kode } \\
\text { Risiko }\end{array}$} & \multirow{3}{*}{$\begin{array}{c}\text { Tipe } \\
\text { Respon }\end{array}$} & \multirow{3}{*}{$\begin{array}{c}\text { Respon Terhadap } \\
\text { Risiko }\end{array}$} & \multicolumn{8}{|c|}{ Kontraktor } \\
\hline & & & & \multicolumn{4}{|c|}{ BUMN } & \multicolumn{4}{|c|}{ Swasta } \\
\hline & & & & $\mathbf{A}$ & B & $\mathrm{C}$ & D & $\mathbf{W}$ & $\mathbf{X}$ & $\mathbf{Y}$ & $\mathbf{Z}$ \\
\hline MR1 & M1 & Mitigate & $\begin{array}{c}\text { Menerbitkan } \\
\text { kebijakan } \\
\text { kebijakan, Juklak } \\
\text { dan sosialisasi. }\end{array}$ & $\checkmark$ & & & & & & & \\
\hline MR2 & M2 & Mitigate & $\begin{array}{l}\text { Monitoring akses } \\
\text { server }\end{array}$ & $\checkmark$ & & & & & & & \\
\hline MR3 & M2 & Mitigate & $\begin{array}{l}\text { Penerapan sanksi } \\
\text { yang jelas dan } \\
\text { terukur pada setiap } \\
\text { personil yang } \\
\text { melakukan } \\
\text { pelanggaran }\end{array}$ & $\checkmark$ & & & & & & & \\
\hline MR4 & M3 & Mitigate & $\begin{array}{c}\text { Melahirkan konsep } \\
\text { diferensiasi, } \\
\text { Perusahaan fokus } \\
\text { pada kualitas } \\
\text { terbaik dan } \\
\text { kepuasan } \\
\text { pelanggan }\end{array}$ & & & & & & & $\checkmark$ & \\
\hline
\end{tabular}




\subsection{Risiko Hazard}

Pada kelompok risiko hazard, diidentifikasi 2 sub-kelompok risiko, yaitu subkelompok risiko politik, dan sub-kelompok K3 (keselamatan dan kesehatan kerja). Pada sub-kelompok risiko politik, diidentifikasi 1 risiko yang diidentifikasi oleh kontraktor sebagai top risk yang dihadapi perusahaan ditunjukkan pada Tabel 21. Sementara pada sub-kelompok risiko $\mathrm{K} 3$, diidentifikasi 4 risiko yang diidentifikasi oleh kontraktor sebagai top risk yang dihadapi perusahaan ditunjukkan pada Tabel 22.

Tabel 21. Indentifikasi Risiko Hazard-Politik

\begin{tabular}{|c|c|c|c|c|c|c|c|c|c|}
\hline \multirow{3}{*}{$\begin{array}{l}\text { Kode } \\
\text { Risiko }\end{array}$} & \multirow{3}{*}{ Identifikasi Risiko } & \multicolumn{8}{|c|}{ Kontraktor } \\
\hline & & \multicolumn{4}{|c|}{ BUMN } & \multicolumn{4}{|c|}{ Swasta } \\
\hline & & $\mathbf{A}$ & $\mathbf{B}$ & $\mathbf{C}$ & $\mathbf{D}$ & $\mathbf{W}$ & $\mathbf{X}$ & $\mathbf{Y}$ & $\mathbf{Z}$ \\
\hline $\mathrm{O} 1$ & $\begin{array}{c}\text { Stabilitas politik (pergantian pejabat } \\
\text { daerah dan negara) Tahun } 2014\end{array}$ & & & $\checkmark$ & $\checkmark$ & $\checkmark$ & & & $\checkmark$ \\
\hline $\mathrm{O} 2$ & $\begin{array}{c}\text { Stabilitas politik (pergantian pejabat } \\
\text { daerah dan negara) Tahun } 2018\end{array}$ & & & & & & & $\checkmark$ & $\checkmark$ \\
\hline
\end{tabular}

Tabel 22. Respon Terhadap Risiko Hazard - K3

\begin{tabular}{|c|c|c|c|c|c|c|c|c|}
\hline \multirow{3}{*}{$\begin{array}{l}\text { Kode } \\
\text { Risiko }\end{array}$} & \multirow{3}{*}{ Identifikasi Risiko } & \multicolumn{7}{|c|}{ Kontraktor } \\
\hline & & \multicolumn{4}{|c|}{ BUMN } & \multicolumn{3}{|c|}{ Swasta } \\
\hline & & $\mathbf{A}$ & B & $\mathbf{C}$ & $\mathbf{D}$ & $\mathbf{W}$ & $\mathbf{X}$ & $\mathbf{Y}$ \\
\hline N1 & Kecelakaan Kerja (Tahun 2014) & & & & & $\checkmark$ & $\checkmark$ & \\
\hline $\mathrm{N} 2$ & Kecelakaan Kerja (Tahun 2015) & & & & & $\checkmark$ & $\checkmark$ & \\
\hline N3 & Kecelakaan Kerja (Tahun 2017) & & $\checkmark$ & & & $\checkmark$ & $\checkmark$ & \\
\hline N4 & Kecelakaan Kerja (Tahun 2018) & & $\checkmark$ & & & $\checkmark$ & $\checkmark$ & \\
\hline
\end{tabular}

Dari hasil analisis perbandingan identifikasi risiko, berikut perbandingan perencanaan respon terhadap risiko ditunjukkan pada Tabel 23 dan Tabel 24.

Tabel 23. Respon Terhadap Risiko Hazard- Politik

\begin{tabular}{|c|c|c|c|c|c|c|c|c|c|c|c|}
\hline \multirow{3}{*}{$\begin{array}{l}\text { Kode } \\
\text { Respon }\end{array}$} & \multirow{3}{*}{$\begin{array}{l}\text { Kode } \\
\text { Risiko }\end{array}$} & \multirow{3}{*}{$\begin{array}{l}\text { Tipe } \\
\text { Respon }\end{array}$} & \multirow{3}{*}{$\begin{array}{c}\text { Respon Terhadap } \\
\text { Risiko }\end{array}$} & \multicolumn{8}{|c|}{ Kontraktor } \\
\hline & & & & \multicolumn{4}{|c|}{ BUMN } & \multicolumn{4}{|c|}{ Swasta } \\
\hline & & & & $\mathbf{A}$ & B & $\mathbf{C}$ & D & $\mathbf{W}$ & $\mathbf{X}$ & $\mathbf{Y}$ & $\mathbf{Z}$ \\
\hline OR1 & $\begin{array}{l}\mathrm{O} 1, \\
\mathrm{O} 2\end{array}$ & Accept & $\begin{array}{l}\text { Perusahaan bersiap } \\
\text { menerima dampak dari } \\
\text { kestabilan politik }\end{array}$ & & $\checkmark$ & $\checkmark$ & & $\checkmark$ & & $\checkmark$ & $\checkmark$ \\
\hline OR2 & $\begin{array}{l}\mathrm{O} 1 \\
\mathrm{O} 2\end{array}$ & Mitigate & $\begin{array}{l}\text { Perusahaan bersikap } \\
\text { netral pada saat pemilu }\end{array}$ & & & $\checkmark$ & & & & & $\square$ \\
\hline
\end{tabular}


Tabel 24. Respon Terhadap Risiko Hazard- K3

\begin{tabular}{|c|c|c|c|c|c|c|c|c|c|c|c|}
\hline \multirow{3}{*}{$\begin{array}{l}\text { Kode } \\
\text { Respon }\end{array}$} & \multirow{3}{*}{ Kode Risiko } & \multirow{3}{*}{$\begin{array}{c}\text { Tipe } \\
\text { Respon }\end{array}$} & \multirow{3}{*}{$\begin{array}{c}\text { Respon } \\
\text { Terhadap } \\
\text { Risiko }\end{array}$} & \multicolumn{8}{|c|}{ Kontraktor } \\
\hline & & & & \multicolumn{4}{|c|}{ BUMN } & \multicolumn{4}{|c|}{ Swasta } \\
\hline & & & & $\mathbf{A}$ & B & $\mathrm{C}$ & D & $\mathbf{W}$ & $\mathbf{X}$ & $\mathbf{Y}$ & $\mathbf{Z}$ \\
\hline NR1 & $\begin{array}{c}\mathrm{N} 1, \mathrm{~N} 2, \mathrm{~N} 3, \\
\mathrm{~N} 4\end{array}$ & Mitigate & $\begin{array}{c}\text { Perusahaan } \\
\text { menerapkan } \\
\text { standar } \\
\text { SMK3 }\end{array}$ & & $\checkmark$ & & & $\checkmark$ & $\checkmark$ & & \\
\hline NR2 & $\begin{array}{c}\text { N1, N2, N3, } \\
\text { N4 }\end{array}$ & Mitigate & $\begin{array}{c}\text { Perusahaan } \\
\text { merekrut } \\
\text { ahli K3 }\end{array}$ & & $\checkmark$ & & & & & & \\
\hline
\end{tabular}

\section{Diskusi}

Dari hasil analisis identifikasi risiko pada sub-kelompok risiko pendanaan pada kelompok risiko finansial, risiko likuiditas, keterlambatan pembayaran proyek dan piutang diidentifikasi menjadi top risk perusahaan kontraktor baik BUMN dan swasta. Top risk yang membedakan kontrarktor BUMN dan swasta dalam hal pendanaan pada tingkat proyek yaitu risiko denda proyek yang diidentifikasi oleh kontraktor swasta. Pada perencanaan respon terhadap risiko, kontraktor BUMN dan swasta secara umum memiliki respon yang sama, yaitu berupa karakteristik respon risiko mitigate ( kebijakan perusahaan dan monitoring kondisi), avoid (proses hukum).

Sementara pada sub kelompok ekonomi, top risk yang diidentifikasi pada ekonomi makro yaitu fluktuasi nilai tukar mata uang. Sementara itu perbedaan identifikasi antara kontraktor BUMN dan kontraktor swasta terdapat pada identifikasi risiko pada tingkat proyek berupa risiko kenaikan harga material dan kenaikan biaya konstruksi yang menjadi perhatian utama kontraktor swasta. Pada perencanaan respon terhadap risiko, kontraktor BUMN dan swasta secara umum memiliki respon yang sama, yaitu berupa karakteristik respon risiko mitigate ( kebijakan perusahaan dan monitoring kondisi).

Pada hasil analisis identifikasi risiko pada sub-kelompok risiko sumber daya manusia pada kelompok risiko operasional, risiko jumlah dan kualitas sumber daya manusia. Pada perencanaan respon terhadap risiko, respon mitigate dilakukan oleh kontraktor BUMN dan swasta berupa pelatihan dan perekrutan pada tingkat perusahaan. Sementara pada kontraktor swasta, secara khusus melakukan strategi perekrutan pegawai secara ketat untuk menghindari (avoid) risiko sumber daya manusia.

Pada hasil analisis identifikasi risiko pada sub-kelompok risiko aspek legal pada kelompok risiko operasional, risiko perubahan kebijakan pemerintah dan sengketa dalam 
kontrak yang menjadi top risk oleh kontraktor BUMN dan kontraktor swasta. Pada respon risiko perubahan kebijakan pemerintah, respon risiko yang digunakan adalah mitigate (monitoring kondisi) dan accept (menerima risiko yang ada dengan mematuhi kebijakkan yang ada). Pada kontraktor swasta, secara khusus menggunakan strategi transfer (menggunakan pihak ketiga menghadapi tuntutan hukum) dalam menghadapai risiko.

Pada hasil analisis identifikasi risiko pada sub-kelompok risiko teknis pada kelompok risiko operasional, risiko keterlambatan proyek, risiko pemilihan mitra, dan risiko supply material menjadi top risk yang dihadapi oleh kontraktor BUMN dan kontraktor swasta. Risiko pada tingkat proyek berupa risiko lokasi baru dan kepuasan pelanggan menjdai perhatian utama dari kontraktor swasta. Sementara pada perencanaan respon risiko, strategi avoid dan mitigate digunakan untuk menghadapi risiko yang ada.

Pada hasil analisis identifikasi risiko pada sub-kelompok risiko persaingan usaha pada kelompok risiko strategi, risiko kompetitif persaingan usaha menjadi top risk yang diidentifikasi oleh kontraktor BUMN dan kontraktor swasta. Terdapat perbedaan cukup signifikan pada risiko persaingan usaha, dimana kontraktor BUMN lebih berfokus pada risiko anak perusahaan, sementara kontraktor swasta lebih berfokus pada penuruanan jumlah proyek. Pada respon terhadap risiko terdapat perbedaan cukup signifikan pada risiko persaingan usaha, yaitu kontraktor BUMN menggunakan strategi mitigate berupa melakukan perjanjian minimum volume proyek yang diberikan oleh pemerintah dan menggandeng tenaga ahli konsultan untuk meningkatkan kapasitas perusahaan. Sementara pada kontraktor swasta, strategi mitigate yang dilakukan adalah melakukan joint venture dan rencana merambah bidang proyek infrastruktur untuk mengejar pendapat perusahaan.

Pada sub-kelompok risiko sosial dan lingkungan, risiko gangguan sosial kepada masyarakat sekitar akibat pekerjaan serta kerusakan lingkungan menjadi top risk yang diidentifikasi oleh kontraktor BUMN dan kontraktor swasta. Respon terhadap risiko yang dilakukan cenderung sama yaitu mitigate (berkoordinasi dengan masyarakat sekitar serta penerapan standar manajemen lingkungan proyek).

Pada hasil analisis identifikasi risiko pada sub-kelompok risiko politik pada kelompok risiko hazard, risiko pergantian kepala daerah dan kepala negara diidentifikasi sebagai top risk oleh kontraktor BUMN dan kontraktor swasta. Identifikasi risiko politik ini pun diidentifikasi pada tahun-tahun menjelang pemilu presiden (2014 dan 2018). Respon risiko yang direncanakan kontraktor BUMN dan kontraktor swasta cenderung sama berupa accept atas risiko stabilitas politik yang ada. 
Sementara pada hasil analisis identifikasi risiko pada sub-kelompok risiko K3 pada kelompok risiko hazard, risiko kecelakaan kerja diidentifikasi sebagai top risk oleh kontraktor BUMN dan kontraktor swasta. Perbedaan yang signifikan adalah konsistensi identifikasi risiko, dimana kontraktor swasta lebih konsisten mengidentifikasi risiko kecelakaan kerja proyek sebagai top risk, dibanding dengan kontraktor BUMN yang mengidentifikasi risiko kecelakaan kerja setelah mengalami beberapa kecelakaan kerja pada proyek infrastruktur pada tahun 2017-2018. Perencanaan risiko kecelakaan kerja secara umum kontraktor BUMN dan kontraktor swasta sama-sama menggunakan strategi mitigate (penetapa standar SMK3 pada proyek).

Pada peneltian ini terdapat beberapa keterbatasan. Identifikasi risiko dan strategi respon terhadap risiko pada perusahaan yang dianalisis, terbatas pada top risk perusahaan, belum pada manajemen risiko secara keseluruhan, namun dalam analisis yang dilakukan pada setiap studi kasus, dilakukan analisis risiko dengan perlakuan yang sama, yaitu dilakukan pada top risk perusahaan. Pengembangan penelitian yang disarankan untuk penelitian selanjutnya adalah mencari hubungan manajemen risiko perusahaan kontraktor BUMN dan swasta terhadap kinerja perusahaan (finansial dan harga saham).

\section{Simpulan}

Dari hasil analisis yang telah dilakukan didapatkan simpulan sebagai berikut:

1. Pada identifikasi risiko, kontraktor BUMN memiliki top risk secara umum pada risikorisiko di tingkat perusahaan pada hirarki proses konstruksi, sementara pada kontraktor swasta memiliki top risk secara umum pada risiko-risiko di tingkat proyek pada hirarki proses konstruksi.

2. Pada perencanaan respons terhadap risiko, kontraktor BUMN dan kontraktor swasta memiliki perbedaan signifikan pada risiko persaingan usaha, dimana kontraktor BUMN berfokus pada tingkat perusahaan dan memanfaatkan hubungan entitas dengan pemerintah, sementara kontraktor swasta berfokus pada tingkat meningkatkan kuantitas dan kualita proyek yang dikerjakan.

\section{DAFTAR PUSTAKA}

1. Badan Pusat Statistik (2014) Konstruksi Dalam Angka 2014.

2. Badan Pusat Statistik (2015) Konstruksi Dalam Angka 2015.

3. Badan Pusat Statistik (2016) Konstruksi Dalam Angka 2016.

4. Badan Pusat Statistik (2017) Konstruksi Dalam Angka 2017. 
5. Badan Pusat Statistik (2018) Konstruksi Dalam Angka 2018.

6. Badan Pusat Statistik (2019) Konstruksi Dalam Angka 2019.

7. Badan Pusat Statistik (2020) PDB Indonesia Triwulanan 2014-2018. Available at: https://www.idx.co.id/data-pasar/data-saham/daftar-saham/.

8. Halpin, D. W. L. S. R. (1992) 'Planning and Analysis of Construction Operation'. John Wiley\& Sons, Inc.

9. Kantor Staf Presiden Republik Indonesia (2016) 'KSP 2 Tahun Jokowi JK.pdf', p. 72. Available at: https://kerjanyata.id/portfolio/tiga-fokus-utama-iipembangunan-manusia/.

10. Labombang, M. (2011) 'Manajemen Risiko Dalam Proyek Konstruksi', Jurnal SMARTek, 9(1), pp. 39-46.

11. Prabawani, R. W. (2012) 'Analisis Dampak Risiko Proyek Terhadap Kinerja Proyek( Studi pada Industri Konstruksi di Jawa Tengah Periode Tahun 20012010)', Analisis Dampak Risiko Proyek Terhadap Kinerja Proyek( Studi pada Industri Konstruksi di Jawa Tengah Periode Tahun 2001-2010), 21(2), pp. 7294. doi: 10.14710/jbs.21.2.72-94.

12. Pratama, A. F. (2017) 'Ada Tiga Sumber Pembiayaan Infrastruktur Nasional', Tribunnews.com, 17 November. Available at: https://www.tribunnews.com/bisnis/2017/11/17/ada-tiga-sumber-pembiayaaninfrastruktur-nasional.

13. Project Management Institute (2017) A Guide To The Project Management Or Body Of Knowledge. 6th edn. Pennsylvania: Project Management Institute.

14. PT. Bursa Efek Indonesia (2020) Daftar Saham Sektor Konstruksi. Available at: https://www.idx.co.id/data-pasar/data-saham/daftar-saham/ (Accessed: 4 March '20).

15. PT Acset Indonusa Tbk. $(2014 ; 2015 ; 2016 ; 2017 ; 2018)$ 'Laporan Tahunan'.

16. PT Adhi Karya (Persero) Tbk. (2014; 2015; 2016; 2017; 2018) 'Laporan Tahunan'.

17. PT Jaya Konstruksi Manggala Pratama Tbk.(2014; 2015; 2016; 2017; 2018) 'Laporan Tahunan'.

18. PT Nusa Konstruksi Enjiniring Tbk. (2014; 2015; 2016; 2017; 2018) 'Laporan Tahunan'.

19. PT PP (Persero) Tbk. (2014; 2015; 2016; 2017; 2018) 'Laporan Tahunan'.

20. PT Total Bangun Persada Tbk. (2014; 2015; 2016; 2017; 2018) 'Laporan Tahunan'. 
21. PT Waskita Karya (Persero) Tbk. (2014; 2015; 2016; 2017; 2018) 'Laporan Tahunan'.

22. PT Wijaya Karya (Persero) Tbk. (2014; 2015; 2016; 2017; 2018) 'Laporan Tahunan'. 